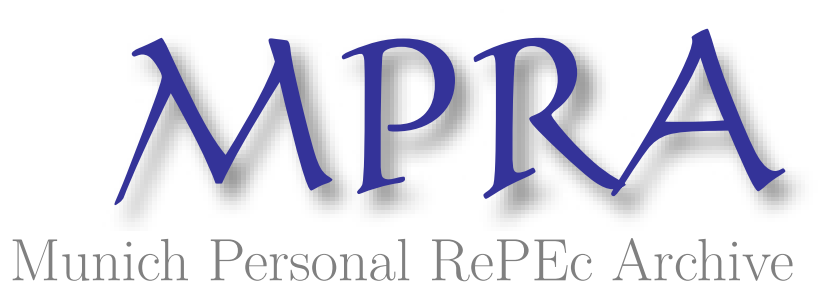

\title{
Islam and Human Development
}

Shaikh, Salman

IBA Karachi

1 January 2014

Online at https://mpra.ub.uni-muenchen.de/53800/

MPRA Paper No. 53800, posted 20 Feb 2014 12:27 UTC 


\title{
Islam and Human Development
}

\author{
Salman Ahmed Shaikh ${ }^{1}$
}

\begin{abstract}
The paper aims to present the Islamic appraisal of established theories in academic literature of development economics, both in classical and neo-classical economics. The paper also explains the Islamic concept of human development and shows it to be more welfare maximizing to humans in their entire life span which includes afterlife. The paper extensively reviews the development literature in mainstream economics and Islamic economics. The paper also uses basic mathematical formulation to explain the concepts. The paper explains the Islamic concept of human development and shows it to be more welfare maximizing to humans and to society. It discusses how Islam is not the source of underdevelopment in Muslim countries and cites the external factors responsible for underdevelopment besides weak internal administration, commitment and management. The paper is one of the few attempts to cite and critically appraise specific development theories from Islamic perspective.
\end{abstract}

Keywords Development Economics, Growth Economics, Economic Development, Poverty, Income Inequality, Income Distribution.

JEL Codes L38 I31 O10

\section{Microeconomic Perspective on Development}

\subsection{Concept of Human Development in Islam}

In Islamic economic literature, Sadeq (1987) explains that Islam emphasizes the achievement of human welfare which is more comprehensive than economic welfare. Chapra (1999) also explains that while economic development is indispensable, it is not sufficient to realize overall human well being by default.

In recent years, even the western concept of development has recognized the wider dimensions of human development and the role of institutions (Mirakhor \& Askari, 2010).

However, human welfare in Islam encompasses economic welfare, but comprises much more than that. The achievement of human welfare is sought in both aspects of human life, i.e. worldly life and eternal life hereafter.

1 Salman Ahmed Shaikh is a Research Associate and teaches Economics courses at Institute of Business Administration (IBA), Karachi. He can be contacted at: salmanashaikh@iba.edu.pk 


\subsection{Mathematical Presentation}

Hence, the human welfare function can be represented by:

$W_{h}=f\left(a W_{t}, a^{m} W_{e}\right)$

Where

$\mathrm{W}_{\mathrm{h}}$ is total human welfare in both aspects of human life.

$W_{t}$ is human welfare in worldly life.

$\mathrm{W}_{\mathrm{e}}$ is human welfare in eternal life hereafter.

We can further explain this function to define $W_{t}$ and $W_{e}$. Both these functions are defined as follows:

$W_{t}=f\left(Z_{t}\right)$

Where $Z_{t}$ is a vector of variables which belong to the category of 'individual specific positive utility gaining choices'.

The constrained set which is a union of three sets is defined as follows:

$\mathrm{C}_{\mathrm{S}}=\left\{\mathrm{C}_{\text {worhip }}\right\} \cup\left\{\mathrm{C}_{\text {self }}\right\} \cup\left\{\mathrm{C}_{\text {society }}\right\} \cup\left\{\mathrm{C}_{\text {people }}\right\}$

$\mathrm{C}_{\text {worhip }}=\{$ five times prayers, one month fasting, obligatory charity, hajj pilgrimage once $\}$

$\mathrm{C}_{\text {self }}=\{$ Acts which harm a person's own ethical and spiritual existence $\}$

$\mathrm{C}_{\text {society }}=\{$ Acts which harm society and its institutions $\}$

$\mathrm{C}_{\text {people }}=\{$ Acts which harm other people, their rights, freedom or property $\}$

Hence, Islam does not deny individuals to fulfill their specific desires they can achieve in career, marriage, family life, business, eating variety of food, wearing variety of clothes, travelling, fine arts etc. It also does not deny temporary indebtedness to achieve these things which can help smooth the intertemporal consumption in this world.

Where Islam intervenes is in identifying for our own benefits the ills in potential acts which may harm us and/or the society and hence reduce the overall human and societal welfare. It is possible that we feel temporary satisfaction in some potential acts, but their long term impact on our spiritual and ethical existence and collective impact on society may reduce the overall human and societal welfare.

We can define the eternal life welfare function as follows:

$W_{e}=f\left(Z_{e}\right)$ 
Where $Z_{e}$ is a vector of variables which belong to the category of 'following Allah's commands which will bring non-decreasing positive utility gain in life hereafter'. These commands do not segregate a human's life in two compartments. Rather, these commands help the humans to live this worldly life in the best possible manner of obedience to Allah and while being responsive and sensitive to the duties that they have to carry out in different roles of life.

Eternal life has no constraint set. Hence, unlike the usual constraints in Economics which limit the optimum value of a function, our constraint sets in worldly life are welfare maximizing in the long run for individuals. The worship set also reinforces the commitment not to violate the other three sets of constraints. The last three constraints which belong to the category of Huquq-ul-lbaad are necessary conditions for welfare maximization of an individual. When they are not violated by individuals, the society also benefits. Islam emphasizes that humans should embrace spiritual rationality as a compliment to material rationality so as to achieve total human welfare.

The achievement of lasting happiness and non-decreasing positive utility will only happen through maximizing both the functions, especially the eternal life function.

For ensuring no corner solution, we shall have both $W_{t}>0$ and $W_{e}>0$.

Plus, Islam requires people to live modest but decent lives and fulfill their own needs and family needs. Islam does not permit monasticism and does not encourage celibacy. Hence, $W_{t}$ not only shall be positive, but also achieve a threshold ' $w$ ' where the ' $w$ ' represents welfare from minimum level of standard of living that qualifies as balanced standard of living within bounds of Islamic injunctions without lavishness and violating the constraint sets.

The constraints of the life may sometimes require a tradeoff between the two functions. In such instances, the trial is to choose the right path ordained by Allah so as to achieve the maximum human welfare in the eternal life.

It is because of the parameter ' $\alpha$ '. Things that we enjoy in this world will be replaced by similar things in afterlife, but they will provide much more utility and they will not be finite nor will our satiation at any time will have binding constraints. The difference between the utility of same bundles traded off in this life for afterlife will be given by the positive multiplier in the exponent of parameter ' $\alpha$ ' that is part of eternal life function.

\subsection{Functional Presentation}

Functional representation of this discussion can make use of the following functional forms:

1. Leontief Perfect Compliments

2. Second Party Preferences 
3. Family or Relational Utility

4. Lexicographic Utility

Using Leontief function, we may have a composite choice representing some socially desirable behavior like altruism etc and other consumption choices representing material goods bundles. Unless the person spends on socially desirable activities along with spending for own consumption, his/her utility will not move to higher indifference curve.

Mathematically,

$$
U(x, y)=\min (\propto X, \beta Y)
$$

Here, ' $x$ ' may represent 'material consumption bundles' and ' $y$ ' may represent 'socially desirable choices'.

In second part preferences, utility function may be represented as:

$$
\boldsymbol{U}=\boldsymbol{U}_{i}\left(\boldsymbol{x}_{i} \boldsymbol{y}_{i}, \boldsymbol{U}_{j}\right)
$$

Here, person 'i' and 'j' are different. We can include scores of other people's utility as parameters. This functional form is richer in that it can help in endogenizing the utility functions of others. Even if scarcity in material resources is a problem to cope up with, one way is to selfishly choose consumption bundles to the extent of seeking exclusivity and satisfying self-esteem with Veblen goods. The other way is to cope up with scarcity in a shared and socially responsible way. Doing this requires incentives which our human welfare function incorporates.

In family or relational utility, we can express utility as:

$$
U=U_{i}\left(x_{i,} y_{i}\right)+\sum_{j=1}^{n} r_{j} U_{j}
$$

Here again, person 'i' and 'j' are different. We can include scores of other people's utility function as parameters. ' $r$ ' measures closeness of relation. This closeness will depend upon relational, emotional, social and communal closeness between person 'i' and ' $j$ '. Islamic principle of brotherhood and equality can further boost the value of ' $r$ ' beyond just family relations.

Family system of Islam brings social capital into existence. It ensures empathy and responsibility. It brings a very lasting and durable social safety net. Islamic injunctions about how to treat orphans ensure social security for individuals with special circumstances. Furthermore, the inheritance laws ensure that the wealth of the deceased is distributed widely among the members of the family of the deceased and 
this permanently and systematically ensures doing away with the concentration of wealth in every generation.

Finally, in lexicographic utility function, Zaman (2005) gave a proposal to take the basic utility function of human beings as a lexicographic ordering.

In his model, every bundle of goods $x$, is evaluated using two functions $(U(x), V(x))$. Given bundles of goods $x$ and $y$, comparison between them is done first on the basis of $U(x)$ and $U(y)$. If $U(x)>U(y)$, then $x$ is preferred to $y$. If $U(x)=U(y)$ then comparison is done by looking at the second component of the utility function, with $\mathrm{x}$ being preferred to $y$ if $V(x)>V(y)$.

According to Zaman (2005), ' $U$ ' is interpreted as the basic needs function. ' $U$ ' will have certain properties to conform to this interpretation. It should have satiation points beyond which additional goods will not add utility. In addition, it should be sensitive only to certain types of goods (basic needs) and insensitive to other types (luxuries).

In his framework, a person is poor when he has a commodity bundle $\mathrm{x}$ such that $\mathrm{U}(\mathrm{x})<\mathrm{U}^{*}$. He states Pareto Principle in Lexicographic form as follows:

An allocation $\left(\mathrm{x}_{1}, \mathrm{x}_{2}, \ldots, \mathrm{x}_{\mathrm{n}}\right)$ of commodity bundles to individuals with utility functions $\left(\mathrm{U}_{\mathrm{i}}, \mathrm{V}_{\mathrm{i}}\right)$ for $i=1,2, \ldots, n$ is socially preferable to an alternative allocation $\left(y_{1}, y_{2}, \ldots, y_{n}\right)$ if either (a) $U_{i}\left(x_{i}\right)>U_{i}\left(y_{i}\right)$ for all $i$, with strict inequality for at least one $i$, or $(b) U_{i}\left(X_{i}\right)=U_{i}\left(y_{i}\right)$ for all $i$, and $V_{i}\left(x_{i}\right)>V_{i}\left(y_{i}\right)$ for all $i$ with strict inequality for at least one $i$.

\section{Macroeconomic Perspective on Development}

\subsection{Determinants of Long Run Growth in Theory}

In long term growth literature, differences in long term growth rates across countries had been explained to a large extent by differences in the rates of savings which also determine a country's investment in productive capacity, human capital and public infrastructure.

Growth literature highlights the importance of capital formation, complimentary investments and physical and social infrastructure. The long term growth literature from Harrod (1939)-Domer (1946), Solow (1956) and to Romer (1986) is almost unanimous on the role of savings and capital accumulation for long term economic growth. Endogenous growth theory sheds light on importance of complimentary investments and public infrastructure that can not only result in increasing returns to scale, but also lead to permanent source of continued long term growth.

\subsection{Appraisal of Development Theories from Islam's Standpoint}

The assumptions and assumed linearity in Rostow's (1959) stages of growth theory is highly simplistic and evidence is against it. Many countries experienced mass 
consumption through credit expansion, but eventually suffered from deep recession. Definition of a traditional society in Rostow's growth theory considers religion to be a source of primitiveness, whereas, in an Islamic society, religion is the core.

Structural transformation, which is considered as a pre-requisite in that theory for the take off stage had been proved to be flawed in many countries when it was forced upon by developed countries extraneously with no regard to peculiarities of individual regions.

In Harrod (1939)-Domer (1946) and Solow's Growth model, the emphasis is on increasing savings and investments and that is supposed to lead to increased productivity corresponding to lower ICOR in Harrod (1939)-Domer (1946) model and hence higher rate of growth and to higher steady state level of output in Solow's Growth model. Savings that result in investment contribute to growth. Essentially, what leads to growth is investment. Savings are only the source of investment funds.

The issue is how to encourage savings and investment in developing countries. Empirically, the savings are much less dependent on real interest rates in developing countries. Savings exist despite the negative real interest rates in most developing countries. In all Structural Adjustment Programmes, IMF and WB insisted on increasing indirect taxes and freeing trade barriers which increased imports, resulted in depreciation of currencies and together with indirect taxes, they fueled inflation. Hence, real interest rates in many of the developing regions have been negative for most of the time. Financial intermediation on interest based credit is not the only source to promote savings and investment especially in developing countries.

Kuznets's (1955) inverted U-hypothesis also seems to be missing support from empirical data. Inequality in USA, China and India increased even after the economies experienced continuous rise in per capita incomes. In fact, the empirical data supports the view that inequality is the cornerstone of economies following maxims of neoclassical counter-revolution. The result is best described by Stieglitz who calls this kind of economics, the 'trickle up' economics than 'trickle down economics'.

Neo-colonial Dependence Model, False-Paradigm Model, and Dualistic-Development Thesis are all effective explanations as contributing causes of underdevelopment, especially of South Asian, African, Latin American \& Middle East countries.

\subsection{Growth \& Governance Stimuli in Islamic Economy}

\subsubsection{Private Property Rights in Islam}

Islamic economic principles honor private property rights and their protection. It implies that market mechanism is admissible and government intervention besides regulation and policy making is not needed in active entrepreneurship or business management (Tahir, 1995).

Islam does not disallow private property rights. Second, private property rights are 
safeguarded by the state after the provision of taxes. Beyond Zakat, Islam also does not give the government the right to fetch people's money and violate private property rights.

Third, rather than keeping other things as it is, Islam has a very clear view on certain institutions like 'interest based lending' which has been chiefly responsible for concentration of wealth, rising inequality and even poverty and is an exploitative form of earning money. Islam by disallowing interest based earnings, exploitative forms of trade and disallowing imposition of excessive taxes from the state beyond Zakat ensures individual freedom in a much wider sense.

\subsubsection{Labor Productivity \& Technical Progress in Islamic Framework}

Most developing countries have lower labor productivity. Some of the reasons why people are not able to increase their productivity include: lack of education and hence lack of employable skills, poor health, malnutrition etc. Islam has made it obligatory for every Muslim, men and women, to educate themselves. Islam has made it obligatory for Muslims to seek permissible source of income through entrepreneurship or offering other factor services. Islam restricts extravagant and lavish use of wealth and resources which will increase the surplus wealth and resources in the hands of earning individuals as compared to the case in unbridled Capitalism.

This surplus wealth is not allowed to be wasted or lavishly used to gain lesser marginal utility for excessive use. Zakat on wealth will redistribute this wealth to users who can gain higher marginal utility by spending it. Besides obligatory Zakat on income and wealth, the direction for Infaaq opens another door for the channeling of surplus wealth transferred to the hands of poor. Islam emphasizes that in place of using the surplus wealth for earning interest, one should pay it to charity.

In a capitalist system, there are regressive taxes and high taxes on income from work. This creates a disincentive to work and to engage in productive enterprise. But, in Islam, there is proportional tax on income and wealth which is neither too low nor too high. Zakat on wealth limits concentration of wealth and encourages circulation of wealth either through Infaaq or through entrepreneurial activities.

Higher investment could take place in an Islamic economy with Zakat (which discourages keeping money idle) and prohibition of interest (which encourages entrepreneurship). In developing countries, the Zakat could substantially boost aggregate demand and it will keep the investment consistently increasing and hence facilitating the permanent rightward shift in steady state level of output.

Output per person outside agriculture as a multiple of that in agriculture, which is eight in Africa and four in Asia and Latin America, was only about two in Europe in $19^{\text {th }}$ century. It shows that there is huge room for potential investment in developing countries and return on capital is much more in developing countries if such investments are carried out. 
Increase in investment through entrepreneurial activities will increase the labor demand and wages. Increase in wages will improve the standard of living of poor labor class and enable them to improve their productivity further. Productivity may also rise with increase in capital per worker.

\section{Is Islam the Cause of Underdevelopment?}

It is observed that many of the developing countries are countries with Muslim majority population. In fact, if we flip this, almost every country with Muslim majority population seems to be underdeveloped. Is this a coincidence or has it anything to do with Islam and its principles. Below, we would like to make few important observations.

\subsection{Exceptional Evidence}

First, there are exceptions to the two statements above throughout history. Even in modern history, there are exceptions and in fact many Muslims countries have achieved progress and development even in western sense of the term. Malaysia and Turkey are good examples. In last thirty years, even the countries like Bangladesh and Indonesia have improved on several development indicators. Moreover, there are millions of Muslims that live in Europe and North America that have contributed to their respective nations and achieved professional success in diverse areas including academics, science, technology, commerce and public offices. Increased acceptance of Islam in developed world support the notion that modern education and science has not given any reason to not believe in Islam to say the least.

Second, the message of Islam historically over the many centuries had been accepted by people of all regions, race, color, gender and whether they live in Muslim majority areas or Muslim minority areas and whether they had been poor or rich. Plus, the message of Islam is much more than the recent attributes which are negatively associated with Islam. That is the only reason why the following of Islam and new converts have even increased in recent times.

Third, most critics like Kuran (1997) make a common mistake of equating Muslims history or Muslim civilization of past or present as representative of Islam. Advent of religion of Islam dates back to the beginning of human existence on earth. The concept of unity of Allah and belief in life hereafter had remained in every prophet of Islam's teachings. Muslims believe in all prophets (pbut) including Moses (pbuh) and Jesus (pbuh). Muhammad (pbuh) is the last of all prophets (pbuh) and the book revealed to Him (pbuh) is the true representative of Islam and its history.

There is need for understanding this clear separation. A major part of Quran is a historic narration of wrongdoings of the people who were addressed by prophets (pbut) in person while spending their lives within them. Islam neither in those times nor now will be reflected by how it is received, taken and followed by Muslims. In fact, there have been several instances in Holy Quran where the believers who lived during the life of 
Prophet Muhammad (pbuh) are also admonished, warned and asked to correct their mistakes.

Presently, the systems and institutions that prevail and especially how they are being managed by the ruling authorities in Muslim majority countries represent gross deviation from Islamic principles. Mirakhor \& Askari (2010) clarified this by writing that the claims of any society to call itself Islamic must be validated by the existence and effective operations of the institutional structure (rules of behavior). They opine that in today's Muslim societies, the core elements of the institutional structure that would designate a system as Islamic are, by and large, notable for their absence.

But, still we see misnomers like 'Islamic world' in debates and academic literature. Part of the mistake is attributed to Muslims too who have followed the authorities (religious and political) who have misused the name of Islam for their benefit. But, this clear separation has to be understood by all so that debates and dialogues can be directed towards principles rather than actions of minority groups taken as Islamic. They are not even taken Islamic in Muslim majority areas and at least if electronic and print media cannot put up sensibility for commercial reasons, the academic discourse needs to avoid such misnomers.

Indeed, there are internal shortcomings in Muslim countries that have led to underdevelopment. But, it has nothing to do with following Islam.

\subsection{External Factors of Underdevelopment}

In this section, we will analyze that has the lacking on implementation front or inadequate institutional framework contributed to underdevelopment and shortcomings in development progress. We will present analysis of why this argument is weak and mention several possible reasons responsible for the underdevelopment which have nothing to do with poor governance and institutions. While poor governance and inadequate institutional framework may have worsened matters, they are not the only factors behind shortcomings in development progress. The policies themselves and the lack of commitment on other ancillary fronts by developed countries have also resulted in underdevelopment.

Coming out of a debt and poverty trap requires consistent growth for a sustainable period. But, international trade restrictions take much of the ability to grow from developing countries. Tariffs charged by high-income countries on goods important to developing countries, such as textiles and agricultural products, remain high. Subsidies of $\$ 350$ billion a year to agricultural producers in Organization for Economic Cooperation \& Development (OECD) countries are another barrier to developing country exports.

Other than tariffs, high-income countries accuse developing countries of not following environmental standards, Technical Barrier to Trade (TBT), Sanitary \& Phyto-Sanitary Barriers to Trade (SBT), Kyoto Protocol etc. This further reduces the ability and capacity 
of developing countries to gain from exchange and get out of debt and poverty trap. High-income countries account for half the world's Carbon Di-Oxide $\left(\mathrm{Co}_{2}\right)$ emissions. Plus, high-income countries account for $36 \%$ of emissions of organic water pollution.

Most developing countries are going through a perpetual debt trap which takes away resources that could have been used on development, but instead are used to service compounded debt. In section 7, we give further details on this.

Higher tariffs are levied by developed countries on products involving a higher degree of value addition. In the European Union (EU), for example, processed foods are subjected to a higher tariff than unprocessed foods, and fabrics to a higher tariff than thread. In addition to that, many finished textile goods were not allowed under quantitative restrictions, which is a clear violation of WTO. Even if they can produce processed products more cheaply than the developed countries, tariffs tilted the balance against the developing countries.

This 'tariff escalation' means that developing countries are discouraged to enhance their industrial base and capacity and move from their traditional colonial trading pattern of exporting raw materials and simple manufactures to be exporting value added goods.

Reducing trade barriers was said to benefit consumers as they will have range of competitive products at their disposal. But, consumers earn through factor payments that come through producers. If domestic producers will be crowded out of the market in a no-trade barrier regime; then, consumers will lose jobs and their purchasing power will decrease subsequently. Furthermore, it may also cause brain drain with domestic industries closing and bright minds migrating to the developed world.

The export subsidies provided by developed countries to their inefficient sectors enable the inefficient sector to become efficient artificially and crowd out the developing countries by overproducing and then dumping these goods in the third world countries. If the supply exceeds demand, developed countries have not been reluctant to dump their production in sea if they can't do it in the developing countries!

By providing export subsidies to their inefficient sectors, developed countries create distortions in trade and misappropriations in resource allocation. The export subsidies paid by the developed countries to their inefficient agriculture sector are funded through the proceeds of exports. Hence, these are cross subsidies in reality. Therefore, effectively these subsidies are paid by the developing countries. Developed countries charge huge premium for value addition that is not in line with their out-of-pocket costs.

Agriculture is still the most important sector in developing countries in terms of achieving growth, and sourcing funds for development and redistribution efforts as the evidence from Table 1 and figure 1 shows. 
Table 1: Share of Agriculture (\%) in GDP and Employment in Developing countries

\begin{tabular}{|lllll|}
\hline \multicolumn{5}{|c|}{ Agriculture Share in Less Developed Countries } \\
& 1980 & 1990 & 2000 & 2006 \\
In Employment (\%) & 79.5 & 76 & 70.8 & 68.6 \\
In GDP (\%) & 30 & 29.5 & 30.2 & 28 \\
\hline
\end{tabular}

Source: World Development Indicators 2008, World Bank

Figure 1: Agricultural Subsidies by Key Developed Countries

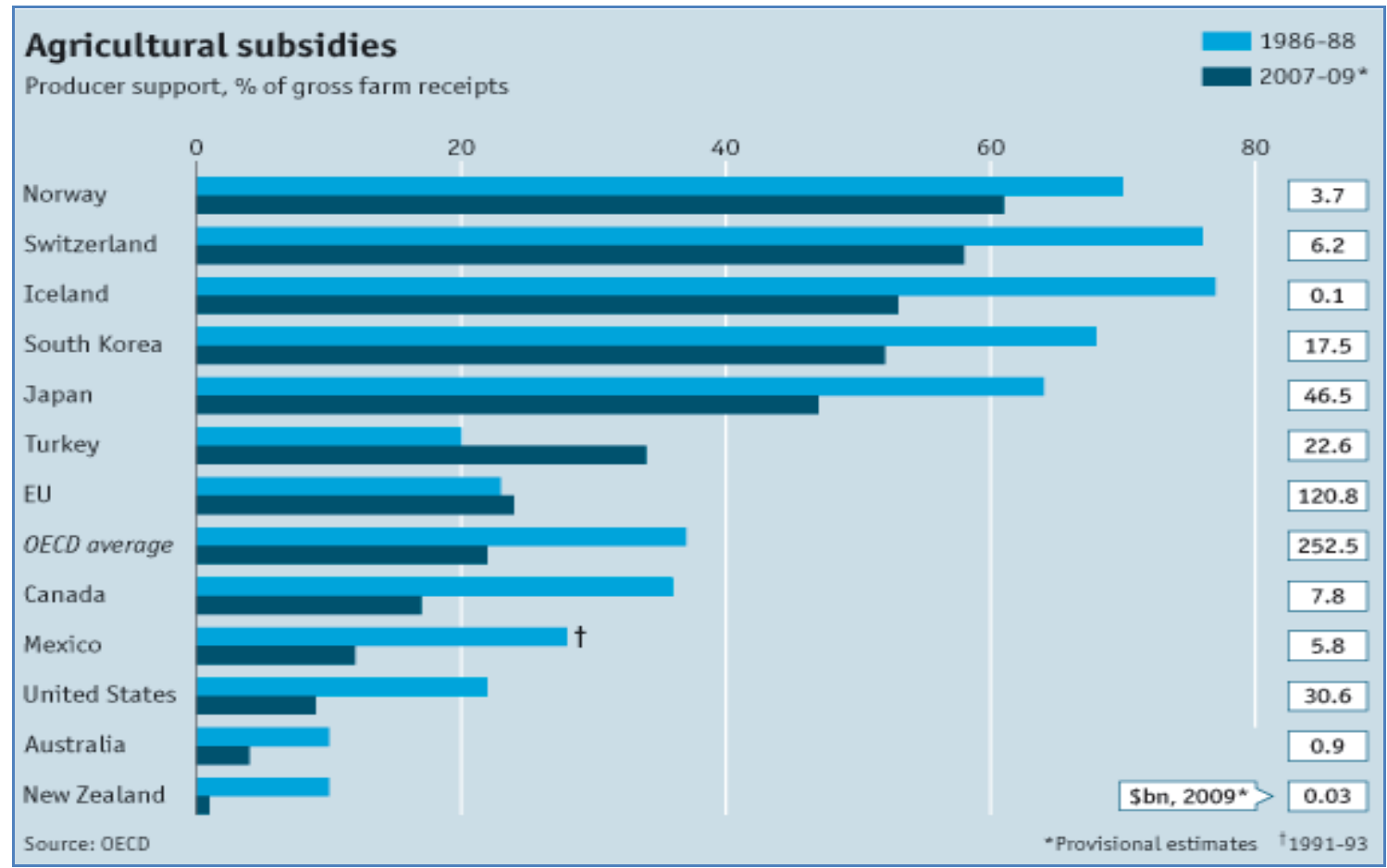

Source: The Economist

Brown (2002), former head of the United Nations Development Program, estimated that farm subsidies cost poor countries about $\$ 50$ billion a year in lost agricultural exports. $\mathrm{He}$ concluded that this amount is the equivalent of today's level of development assistance.

Eventually, a developing country will have to submit itself before the international financial institutions that are able to exert extraordinary influence -not limited to economic but also political- in the developing country. Therefore, the role of IMF, WB, World Trade Organization (WTO) and the adaptation of SAP and Free-Float exchange rate systems are all interrelated in their objectives to maintain the status quo of supremacy of developed world over developing countries. Mercantilism stands completely opposite to free trade theory, but, the former was supported when Europe needed it. 
To summarize, in this section, we analyzed that lacking on implementation front or inadequate institutional framework is not chiefly responsible for the underdevelopment.

\subsection{Negative Effects of Interest Based Loans on Development}

Most developing countries are going through a perpetual debt trap which takes away resources that could have been used on development, but instead are used to service compounded debt.

Continent of Africa seems to be most affected by the debt crisis. Africa's debt stock in 1970 was $\$ 11$ billion and Africa's debt stock in 2008 stood at $\$ 215$ billion. Furthermore, Sub Saharan Africa receives $\$ 10$ billion in aid but loses $\$ 14$ billion in debt payments per year (Africa Action, 2008). It shows that on net basis, even after receiving aid, outflow is more than inflow. If this trend persists in future, one can see how it will perpetuate the debt trap.

Currently, Africa's total external debt stands at $\$ 300$ billion. Many African countries spend more on debt than either on health or education. For example, Cameroon, Ethiopia, Gambia, Guinea, Madagascar, Malawi, Mauritania, Senegal, Uganda and Zambia all spent more on debt than on health in 2002. GNP per capita in Sub-Saharan Africa is $\$ 308$ while external debt per capita stands at $\$ 365$. Total debt per capita which includes internal debt per capita as well would be even higher!

Just to cite one example, Nigeria borrowed around $\$ 5$ billion and has paid about $\$ 16$ billion, but still owes $\$ 28$ billion. Regrettably, 7 million children die each year as a result of the debt crisis.

Ajayi \& Oke (2012) found in an empirical study for Nigeria that external debt burden had an adverse effect on the per capita income and led to devaluation of the currency, increase in unemployment, social strife and poor educational system.

Easterly (2002) presented the similar empirical evidence which shows a negative effect of indebtedness on growth. Explaining the evidence, he stated that the paradox of debt is that heavily indebted poor countries (HIPCs) became more heavily indebted after two decades of debt relief efforts. He stated that even concessional financing, a form of debt relief also failed to reduce net present value of debt. According to him, the record is not encouraging for the success of current debt relief efforts.

Cunningham (1993) collecting evidence for the period 1971-1987 from 16 HIPCs found a significant negative relationship between the growth of debt burden and economic growth in these countries.

It is not just Africa that is suffering from the debt crisis. Other developing regions are also having the same negative impacts. Malik et al. (2010) provided the empirical evidence for Pakistan's economy which shows negative and significant relationship of 
external debt with economic growth. Currently, Pakistan pays around Rs 1,000 billion in debt servicing which is far below its development spending. Most of the debt is of the nature of deadweight debt (i.e. used to pay off other debts or for non-development spending). It shows that about half of the tax revenue goes to the lenders in paying of interest.

\section{Conclusion}

The paper presented the Islamic appraisal of established theories in academic literature of development economics, both in classical and neo-classical economics. We also explained the Islamic concept of human development and showed it to be more welfare maximizing to humans in their entire life span which includes afterlife. We discussed how Islam is not the source of underdevelopment in Muslim countries and cited the external factors responsible for underdevelopment besides weak internal administration, commitment and management.

\section{References}

Africa Action (2008). "Campaign to Cancel Africa's Debt", Retrieved from: http://www.africaaction.org/campaign new/debt.php

Ajayi, L. Boboye \& Oke, M. Ojo (2012). "Effect of External Debt on Economic Growth and Development of Nigeria". International Journal of Business and Social Science, Vol 3 (12), pp. 297-304.

Brown, Mark Malloch (2002). UNDP Administrator, Address at Makerere University, Kampala, Uganda.

Chapra, M. Umer (1999). Islam and Economic Development: A Discussion within the Framework of Ibn Khaldun's Philosophy of History, Proceedings of the Second Harvard University Forum on Islamic Finance: Islamic Finance into the $21^{\text {st }}$ Century Cambridge, Massachusetts, Center for Middle Eastern Studies, Harvard University, pp. 23-30.

Cunningham, Rosemary T. (1993). "The Effects of Debt Burden on Economic Growth in Heavily Indebted Developing Nations". Journal of Economic Development. Vol. 18 (1), pp. 115-126.

Domar, Evsey (1946). Capital Expansion, Rate of Growth, and Employment. Econometrica, 14 (2), pp. 137-47.

Easterly, William (2002). "How Did Heavily Indebted Poor Countries Become Heavily Indebted? Reviewing Two Decades of Debt Relief", World Development, Vol 30 (10), pp. 1677-1696. 
Harrod, Roy F. (1939). An Essay in Dynamic Theory. The Economic Journal, 49 (193), pp. 14-33.

Kuran, Timur (1997) "Islam and Economic Underdevelopment: An Old Puzzle Revisited," Journal of Institutional and Theoretical Economics, Vol 153 (1), pp. $41-71$.

Kuznets, Simon. (1955). "Economic Growth and Income Inequality". American Economic Review, Vol 45 (1), pp. 1-28.

Malik, Shahnawaz, Hayat, M. Khizer \& Hayat, M. Umer (2010). "External Debt and Economic Growth: Empirical Evidence from Pakistan". International Research Journal of Finance and Economics, Issue 44, pp. 88-97.

Mirakhor, Abbas \& Askari, Hossein (2010), Islam and the Path to Human and Economic Development, New York: Palgrave Macmillan.

Romer, Paul M., (1986). Increasing Returns and Long-Run Growth, Journal of Political Economy, 94 (5), pp. 1002-37.

Sadeq, A.H.M (1987). Economic Development in Islam, Journal of Islamic Economics, Vol 1 (1), pp. $35-45$.

Solow (1956), Robert M. (1956). A Contribution to the Theory of Economic Growth, Quarterly Journal of Economics, 70 (1), pp. 65-94.

Tahir, Sayyid (1995). Islamic Perspective on Economic Development, Pakistan Development Review, 34 (4), pp. 845 - 856.

W. W. ROSTOW (1959), The Stages of Economic Growth, The Economic History Review, 12 (1), pp. 1-16.

Zaman, Asad (2005), "Towards a New Paradigm for Economics", Journal of King Abdul Aziz University: Islamic Economics, Vol 18 (2), pp. 49 - 59. 